\title{
Phosphate Removal from Wastewater in Batch System Using Waste Mussel Shell
}

\author{
Nur Atikah Abdul Salim 1,4,* (D) , Mohamad Ali Fulazzaky ${ }^{2}$, Muhammad Abbas Ahmad Zaini ${ }^{3}$, Mohd Hafiz \\ Puteh 1,4,*, Mohd Hairul Khamidun 5,*, Abdull Rahim Mohd Yusoff ${ }^{6}$, Noorul Hudai Abdullah ${ }^{7}$, Noraziah \\ Ahmad 1, Zainab Mat Lazim ", Maria Nuid ${ }^{1}$
}

1 School of Civil Engineering, Faculty of Engineering, Universiti Teknologi Malaysia, 81310 UTM Johor, Malaysia

2 Department of Postgraduate Studies, Djuanda University, 16720 Bogor, Indonesia

3 School of Chemical and Energy Engineering, Faculty of Engineering, Universiti Teknologi Malaysia, 81310 UTM Johor, Malaysia

4 Centre for Environmental Sustainability and Water Security, Research Institute for Sustainable Environment, Universiti Teknologi Malaysia, 81310 UTM Johor, Malaysia

5 Faculty of Civil and Environmental Engineering, Universiti Tun Hussein Onn Malaysia, 86400 UTHM, Johor, Malaysia

6 Faculty of Science, Universiti Teknologi Malaysia, 81310 UTM Johor, Malaysia

7 Centre For Diploma Studies, Faculty of Civil Engineering, Universiti Tun Hussein Onn Malaysia, 84600 UTHM, Johor, Malaysia

* Correspondence: atikahsalim@gmail.com (N.A.A.S.); natikah57@live.utm.my (N.A.A.S.); mhafizputeh@utm.my (M.H.P); hairulk@uthm.edu.my (M.H.K.);

Received: 9.11.2020; Revised: 3.12.2020; Accepted: 6.12.2020; Published: 11.12.2020

Abstract: High input of phosphate $\left(\mathrm{PO}_{4}^{3-}\right)$ in rivers can lead to eutrophication, which jeopardizes aquatic life and human health. In this study, $\mathrm{PO}_{4}{ }^{3-}$ was removed from synthetic solution and domestic wastewater treatment plant effluent (DWTPE) by waste mussel shell (WMS). The $\mathrm{PO}_{4}{ }^{3-}$ adsorption by WMS was examined for the initial $\mathrm{PO}_{4}{ }^{3-}$ concentration $\left(7 \mathrm{mg} \mathrm{L}^{-1}\right)$, solution volume $(0.2 \mathrm{~L})$, adsorbent dosage $(4,8,12,16$, and $20 \mathrm{~g})$, and contact time (1-6 d). The batch experiment's optimum performance could reach approximately $75.1 \%$ for the removal of $\mathrm{PO}_{4}{ }^{3-}$ from synthetic solution and approximately $66.2 \%$ for the removal of $\mathrm{PO}_{4}{ }^{3-}$ from DWTPE after a contact time of $5 \mathrm{~d}$. This work suggests that the WMS can remove PO43 from both synthetic solution and DWTPE. Future works are necessary to increase WMS's capacity to adsorb $\mathrm{PO}_{4}{ }^{3-}$ from waters, either by physical or chemical modification.

Keywords: adsorption; domestic wastewater; eutrophication; isotherm model; kinetic model; phosphate; waste mussel shell.

\section{Nomenclature:}

$C_{\mathrm{e}}$ concentration of the solute at equilibrium $\bullet$ number of measurements $\left(\mathrm{mg} \mathrm{L}^{-1}\right)$

$C_{\mathrm{i}} \quad$ solute concentration at initial dimensionless

$C_{\mathrm{f}} \quad$ solute concentration in the solution (mg $\quad p \quad$ number of parameters in the kinetic $\mathrm{L}^{-1}$ )

$E$ removal efficiency $(\%)$

$F_{\mathrm{e}}$ error function

$k_{1} \quad$ PFO constant $\left(\min ^{-1}\right)$

$k_{2} \quad$ PSO constant $\left(\mathrm{g} \mathrm{mg}^{-1} \mathrm{~min}^{-1}\right)$ experiment

$K_{\mathrm{F}} \quad$ Freundlich constant $\left(\mathrm{mg} \mathrm{g}^{-1}\right)$

$q \quad$ adsorption capacity $\left(\mathrm{mg} \mathrm{g}^{-1}\right)$

$q_{\mathrm{e}} \quad$ adsorption capacity at equilibrium $\left(\mathrm{mg} \mathrm{g}^{-1}\right)$

$q_{\max } \quad$ maximum adsorption capacity $\left(\mathrm{mg} \mathrm{g}^{-1}\right)$

$q_{t(\exp )}$

$K_{\mathrm{L}}$ adsorption energy coefficient $\left(\mathrm{L} \mathrm{mg}^{-1}\right) \quad q_{t(\text { theo })}$ the theoretical value of adsorption capacity $\left(\mathrm{mg} \mathrm{g}^{-1}\right)$

$m$ mass of adsorbent $(\mathrm{g}) \quad t \quad$ adsorption time (min)

(C) 2020 by the authors. This article is an open-access article distributed under the terms and conditions of the Creative Commons Attribution (CC BY) license (https://creativecommons.org/licenses/by/4.0/). 


\section{Introduction}

Phosphorus (P) is a key nutrient that stimulates the development of biological organisms and algae. However, the discharge of an excessive amount of $\mathrm{P}$ into surface water strongly accelerates eutrophication, which threatens aquatic life and human health [1-3]. The effects of the release of $\mathrm{P}$ to surface water have resulted in legislation; the United States Environmental Protection Agency (USEPA), the European Union (EU) Wastewater Directive, and the Malaysia Environmental Quality (Sewage) Regulations 2009 -P.U. (A) 432/2009. The USEPA permits the effluent limit of total $\mathrm{P}$ ranging from 0.1 to $0.5 \mathrm{mg} \mathrm{L}^{-1}$ [4]. Meanwhile, according to the EU Wastewater Directive, P's effluent limit is $2 \mathrm{mg} \mathrm{L}^{-1}$ for $10,000-100,000$ population equivalents [5]. According to the Malaysian effluent standards, the acceptable limit for $\mathrm{P}$ concentration must be less than $5 \mathrm{mg} \mathrm{L}^{-1}$. In contrast, the Malaysian effluent standards have been allowed to release higher P concentration into surface water than the EU Wastewater Directive and USEPA effluent standards. The Malaysian government legislation has paid less attention to the high concentration of $\mathrm{P}$ in effluent, which can initiate the degradation of the environment. The concentration of $\mathrm{P}$ effluent standard needs to be revised to a significant value by the Malaysian government, which would be more realistic to alleviate $\mathrm{P}$ pollution and improve the quality of water.

The excessive amounts of $\mathrm{P}$ can be treated with various methods, such as adsorption, biological and chemical processes. The drawbacks of biological treatment are that the bioconversion is a slow process, and it needs a long start-up time to initiate the treatment process [6]. In contrast, the chemical treatment entails high chemical costs [7]. From all these removal methods, adsorption is the potential technology employed to remove $\mathrm{P}$ from water due to its simple operation, inexpensive, and highly efficient processes [8-10]. Commonly, a wide range of seashell waste can be used as adsorbents for P removal, such as crab carapace [11], cockle shells [12], and oyster shells [13]. These wastes are available in large volumes in certain countries, and most of them are landfilled.

In Malaysia, about 2,000 tonnes per year of waste mussel shells (WMS) are produced, resulting in environmental pollution due to the unpleasant odor dumped in open areas [14]. This problem leads to low quality of living for people in such areas. Approximately 500 tonnes of WMS in Malaysia are used for fertilizers and handicrafts. The remainder (1,500 tonnes) constitutes a serious solid waste problem. WMS was previously used as the adsorbent for heavy metals and dye removal $[15,16]$; however, there is a paucity of studies for describing the removal of phosphate $\left(\mathrm{PO}_{4}{ }^{3-}\right)$ from water using WMS. Therefore, this study scrutinizes the feasibility of using WMS for $\mathrm{PO}_{4}{ }^{3-}$ removal from synthetic solution and domestic wastewater treatment plant effluent (DWTPE). This research's novelty is reflected by discovering a new type of adsorbent derived from waste to remove $\mathrm{PO}_{4}{ }^{3-}$ from an aqueous solution.

\section{Materials and Methods}

\subsection{Adsorption kinetics and isotherms.}

\subsubsection{Kinetic adsorption models.}

Two adsorption kinetic models (i.e., Pseudo-first-order (PFO) and pseudo-second-order (PSO)) were applied to describe the adsorption behavior [17]. PFO equation can be written as [18]:

$$
\ln \left(q_{e}-q_{t}\right)=\ln \left(q_{e}\right)-k_{1} t
$$


PSO equation can be expressed as [19]:

$$
\frac{t}{q_{t}}=\frac{1}{k_{2} q_{e}^{2}}+\frac{t}{q_{e}}
$$

\subsubsection{Isotherm adsorption models.}

The Freundlich and Langmuir isotherm models were used to explain the adsorption phenomena. The Freundlich model describes the surface of the adsorbent is heterogeneous. The stronger active sites are occupied first [20]. The Langmuir model assumes that the adsorption of solute attributed to monolayer adsorption on the surface of adsorbent [21]. The Freundlich equation can be written as [22]:

$$
\ln q_{e}=\ln K_{F}+\frac{1}{n} \ln C_{e}
$$

The Langmuir equation can be expressed as [23]:

$$
\frac{1}{q_{e}}=\frac{1}{K_{L} q_{\max } C_{e}}+\frac{1}{q_{\max }}
$$

\subsection{Adsorbents.}

WMS was used as an adsorbent in this study. The WMS was collected from riverbank areas at Kampung Pasir Putih, Pasir Gudang, Johor, Malaysia. The sample was cleaned with tap water and dried in an oven at $30^{\circ} \mathrm{C}$ for $48 \mathrm{~h}$. The sample was crushed and finally sieved to particle sizes with a range of $0.60-1.18 \mathrm{~mm}$.

\subsection{Synthetic solutions.}

Synthetic solution (i.e., $100 \mathrm{mg} \mathrm{L}^{-1}$ ) was prepared by dissolving $0.1433 \mathrm{~g}$ of anhydrous potassium dihydrogen phosphate $\left(\mathrm{KH}_{2} \mathrm{PO}_{4}\right)$ (analytic grade) into $1 \mathrm{~L}$ of deionized (DI) water in a volumetric flask. The synthetic solution was diluted with DI water to get the desired concentration.

\subsection{Analytical methods.}

The synthetic solution and domestic wastewater compositions were measured according to the Standard Methods for the Examination of Water, Wastewater [24] (Table 1), and the instrumental equipment identified WMS characteristics in Table 2.

\subsection{Domestic wastewater treatment plant effluent.}

The tertiary treatment of secondary municipal effluents to remove $\mathrm{PO}_{4}{ }^{3-}$ is necessary to meet environmental regulations worldwide. In this work, the DWTPE was used in the batch studies with an average $\mathrm{PO}_{4}{ }^{3-}$ concentration of $7 \mathrm{mg} \mathrm{L}^{-1}$ (Table 3). The treatment plant is located at Taman Sri Pulai, Johor, Malaysia.

Table 1. Analytical methods of domestic wastewater.

\begin{tabular}{l|l} 
Parameter & Standard Method \\
\hline $\mathrm{pH}$ & Jenway 350 pH meter \\
\hline Ammonical nitrogen & Nessler method of HACH 8038 \\
\hline Chemical oxygen demand & Reactor digestion method of HACH 8000 \\
\hline Chloride & Mercuric thiocyanate method of HACH 8113 \\
\hline Nitrate & HR cadmium reduction method of HACH 8039 \\
\hline Phosphate & Amino acid method of HACH 8190 \\
\hline Sulfate & SulfaVer4 method of HACH 8051 \\
\hline Suspended solids & Gravimetric method of APHA 2540D
\end{tabular}


Table 2. Characterization of the adsorbent.

\begin{tabular}{l|l} 
Characteristic & Instrument \\
\hline Surface morphology & Scanning electron microscope (SEM) (Model TM3000, Hitachi, Japan) \\
\hline Chemical composition & Energy Dispersive X-Ray Fluorescence (EDXRF) Spectrometer (Rigaku, Japan) \\
\hline Functional group & Fourier Transform Infrared (FTIR) Spectroscopy (IRTracer-100, Shimadzu, Japan) \\
\hline Specific surface area & Surfer analyzer (Surface Analyzer, Thermo Scientific Technologies, Italy) \\
\hline Types of mineral phases & High-Resolution X-Ray Diffractometer (XRD) (Bruker D8 Advance, Jerman)
\end{tabular}

Table 3. Characteristics of the DWTPE.

\begin{tabular}{l|c|c|c} 
Parameter & Unit & Value & \\
\hline & & Range & Average \\
\hline $\mathrm{PO}_{4}^{3-}$ & $\mathrm{mg} \mathrm{L}^{-1}$ & $5.6-8.4$ & 7.0 \\
\hline $\mathrm{NH}_{4}{ }^{+}$ & $\mathrm{mg} \mathrm{L}^{-1}$ & $7.4-11.8$ & 10.2 \\
\hline $\mathrm{SO}_{4}{ }^{2-}$ & $\mathrm{mg} \mathrm{L}^{-1}$ & $8-15$ & 12.5 \\
\hline $\mathrm{Cl}^{-}$ & $\mathrm{mg} \mathrm{L}^{-1}$ & $10-37.5$ & 18.01 \\
\hline $\mathrm{NO}_{3}{ }^{-}$ & $\mathrm{mg} \mathrm{L}^{-1}$ & $0.1-1.1$ & 0.48 \\
\hline $\mathrm{COD}$ & $\mathrm{mg} \mathrm{L}^{-1}$ & $73-151$ & 106.7 \\
\hline $\mathrm{SS}$ & $\mathrm{mg} \mathrm{L}^{-1}$ & $12-84$ & 31.2 \\
\hline $\mathrm{pH}$ & - & $7.2-8.5$ & 7.66
\end{tabular}

\subsection{Batch experiments.}

The batch experiments were conducted to determine adsorption isotherm and kinetic. The kinetic experiments were carried out by adding 4, 12, and $20 \mathrm{~g}$ of the adsorbent into an Erlenmeyer flask. Each flask containing 0.2 L of either synthetic solution or the DWTPE with a concentration of $7 \mathrm{mg} \mathrm{PO} 4{ }^{3-} \mathrm{L}^{-1}$, respectively. Note that the concentration of $\mathrm{PO}_{4}{ }^{3-}$ in the synthetic solution for the adsorption of a single solute was adjusted to having the same concentration as those that have been verified in the DWTPE for the adsorption of multifarious solutes. Each sample solution was shaken from 1 to $6 \mathrm{~d}$ at $160 \mathrm{rpm}$, and then the concentrations of $\mathrm{PO}_{4}{ }^{3-}$ in each flask were determined at certain time intervals until the adsorbent saturates. The sample solutions were centrifuged, and the concentrations of $\mathrm{PO}_{4}{ }^{3-}$ in each flask were monitored using the HACH DR 6000 UV-Vis Spectrophotometer. The PFO and PSO models were applied to understand the kinetics of the adsorption of $\mathrm{PO}_{4}{ }^{3-}$ onto WMS from either the synthetic solution or the DWTPE.

The isotherm experiments were carried out by adding 4, 8, 12, 16, and $20 \mathrm{~g}$ of the adsorbent into a different flask containing $0.2 \mathrm{~L}$ of either synthetic solution or the DWTPE with a concentration of $7 \mathrm{mg} \mathrm{PO} 4^{3-} \mathrm{L}^{-1}$, respectively. Each sample solution was shaken ranged from 1 to $6 \mathrm{~d}$, depending on the time period of the isotherm equilibrium of $\mathrm{PO}_{4}{ }^{3-}$. The sample solutions were centrifuged, and the concentrations of $\mathrm{PO}_{4}{ }^{3-}$ in each flask were monitored using the HACH DR 6000 UV-Vis Spectrophotometer. Two isotherm models (i.e., Freundlich and Langmuir) were used to describe the adsorption isotherms of $\mathrm{PO}_{4}{ }^{3-}$ for the synthetic solution and the DWTPE.

Each batch adsorption experiment was conducted in duplicate. Eq. (5) and Eq. (6) were used to calculate q and E's value, respectively.

$$
\begin{gathered}
q=\frac{\left(C_{i}-C_{f}\right) \times V}{m} \\
E=\frac{C_{i}-C_{f}}{C_{i}} \times 100 \%
\end{gathered}
$$




\section{Results and Discussion}

\subsection{Physical and chemical characteristics of the WMS.}

The WMS's chemical composition is important due to WMS's ability to adsorb a solute such as $\mathrm{PO}_{4}{ }^{3-}$ from waters greatly depends on its physical and chemical properties. The major chemical compositions of WMS discovered in this study are $\mathrm{CaO}(96.50 \%)$ and $\mathrm{Na}_{2} \mathrm{O}(2.62 \%)$, while the minor compositions are $\mathrm{Al}_{2} \mathrm{O}_{3}(0.13 \%), \mathrm{Fe}_{2} \mathrm{O}_{3}(0.03 \%), \mathrm{P}_{2} \mathrm{O}_{5}(0.03 \%)$, and $\mathrm{K}_{2} \mathrm{O}$ $(0.02 \%)$, as shown in Table 4 . In this study, the WMS used as an adsorbent for the adsorption of $\mathrm{PO}_{4}{ }^{3-}$ has a BET surface area of $1.83 \mathrm{~m}^{2} \mathrm{~g}^{-1}$.

Table 4. Composition of the WMS (wt.\%).

\begin{tabular}{l|l|l|l|l|l}
$\mathbf{C a O}$ & $\mathbf{N a}_{2} \mathbf{O}$ & $\mathbf{A l}_{2} \mathbf{O}_{\mathbf{3}}$ & $\mathbf{F e}_{2} \mathbf{O}_{\mathbf{3}}$ & $\mathbf{P}_{\mathbf{2}} \mathbf{O}_{\mathbf{5}}$ & $\mathbf{K}_{\mathbf{2}} \mathbf{O}$ \\
\hline 96.50 & 2.62 & 0.13 & 0.03 & 0.03 & 0.02
\end{tabular}

The images from the SEM micrograph with 1500, 6000, and 10000 times magnification were used to examine the WMS's surface morphology, as shown in Figure 1. The figure (Figure 1a and Figure 1b) shows that the surface feature of WMS has no regular structure [25] and possesses a compact surface with a low porosity structure [26]. The SEM micrograph image with 10000 times magnification exhibits small pores at the WMS surface (Figure 1c).

The XRD pattern (Figure 2) of the WMS sample indicates that aragonite $\left(\mathrm{CaCO}_{3}\right)$ is the WMS's major component. The other components listed on the XRD pattern are calcium oxide $(\mathrm{CaO})$, sodium oxide $\left(\mathrm{Na}_{2} \mathrm{O}\right)$, iron oxide $\left(\mathrm{Fe}_{2} \mathrm{O}_{3}\right)$, and quartz $\left(\mathrm{SiO}_{2}\right)$. Several researchers have reported that aragonite and $\mathrm{CaO}$ have good adsorption ability for $\mathrm{PO}_{4}{ }^{3-}$ ions $[12,27]$.
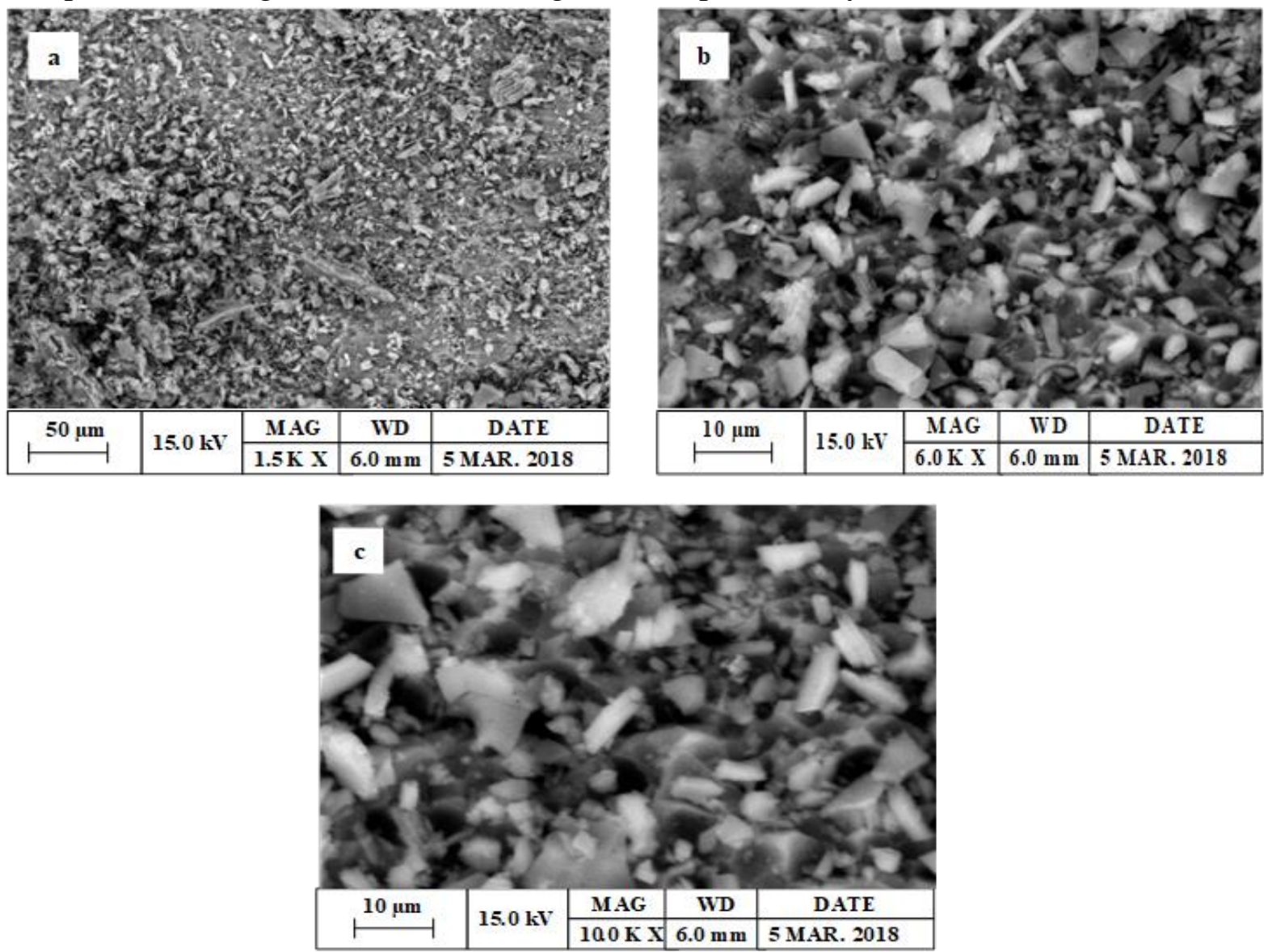

Figure 1. SEM photomicrograph of WMS: (a) 1500 times magnifications (b) 6000 times magnifications (c) 10000 times magnifications. 
The FTIR spectra (Figure 3 ) of natural and $\mathrm{PO}_{4}{ }^{3-}$ adsorbed WMS were carried out over the range from 600 to $4000 \mathrm{~cm}^{-1}$ and were compared with each other to obtain information on the modifications and surface functional groups [28]. A group (Table 5) of absorption peaks, with a range of the different frequencies from 2 to $17 \mathrm{~cm}^{-1}$ was observed from the FTIR pattern, which is due to $\mathrm{PO}_{4}{ }^{3-}$ stretching vibration of the WMS surface. The position and shape of the $\mathrm{PO}_{4}{ }^{3-}$ stretching band in the FTIR spectra of the WMS are influenced by the nature and position of the surface functional groups. The tetrahedral $\mathrm{PO}_{4}{ }^{3-}$ molecules are coordinated [29].

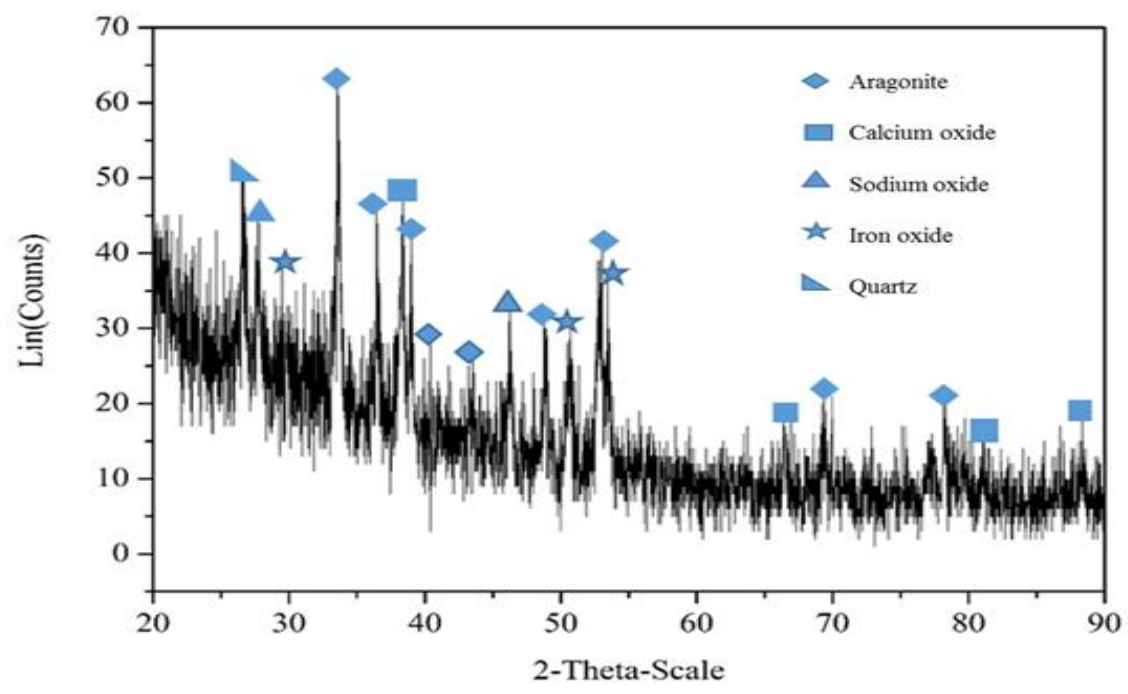

Figure 2. X-ray diffraction patterns of WMS.

Before the adsorption of $\mathrm{PO}_{4}{ }^{3-}$, the FTIR spectral results with two bands observed at 857 and $710 \mathrm{~cm}^{-1}$ would confirm the presence of aragonite [12], [29]. Four shifted bands have a significant change from the frequencies of $710,857,1,451$, and $3,547 \mathrm{~cm}^{-1}$ before adsorption to those of $713,860,1,458$, and $3,564 \mathrm{~cm}^{-1}$, respectively, after adsorption of the $\mathrm{PO}_{4}{ }^{3-}$ ions from synthetic solution onto the WMS. The differences of the frequency spectrum of $17 \mathrm{~cm}^{-1}$ $\left(3,564-3,547 \mathrm{~cm}^{-1}\right)$ is because the $\mathrm{OH}$ stretching bands at the surface of WMS are affected by asymmetric stretching mode of vibration for $\mathrm{PO}_{4}{ }^{3-}$ group [30].

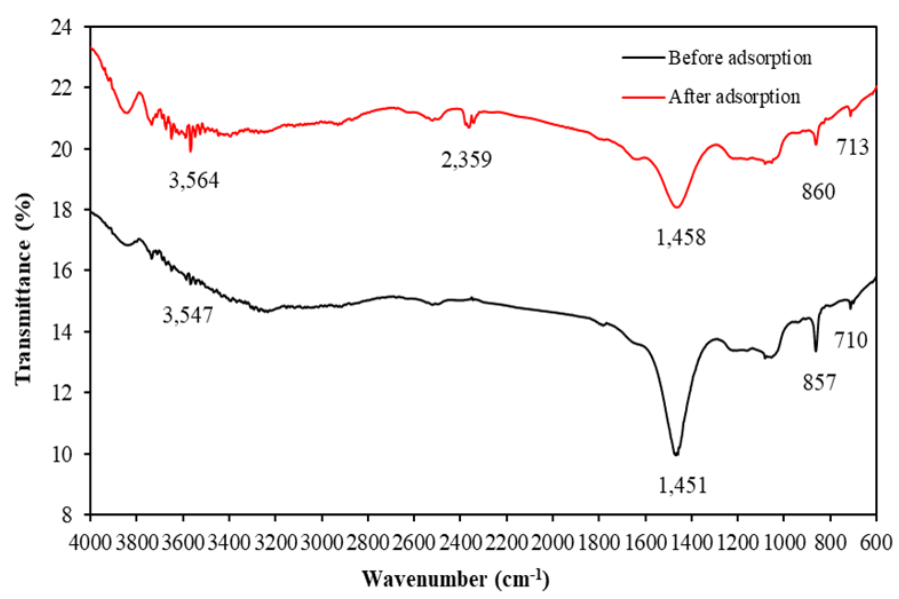

Figure 3. The FTIR spectra of WMS of before and after $\mathrm{PO}_{4}{ }^{3-}$ adsorption.

The influence of the $\mathrm{PO}_{4}{ }^{3-}$ molecules adsorbed onto the surface of WMS on C-O bending may increase by $2 \mathrm{~cm}^{-1}\left(713-710 \mathrm{~cm}^{-1}\right), 3 \mathrm{~cm}^{-1}(860-857)$, and $7 \mathrm{~cm}^{-1}(1,458-$ $1,451)$ frequency spectrum due to ion exchange between $\mathrm{PO}_{4}{ }^{3-}$ and $\mathrm{C}-\mathrm{O}$ functional group. This can affect the stretching because of the vibrations [31]. After the adsorption of $\mathrm{PO}_{4}{ }^{3-}$ solute 
from synthetic solution onto the WMS, a new peak located at $2,359 \mathrm{~cm}^{-1}$ was observed and could be associated with $\mathrm{O}-\mathrm{H}$ stretching vibration of $\mathrm{H}_{2} \mathrm{PO}_{4}$ onto the surface WMS on $\mathrm{C}-\mathrm{O}$, indicating that dihydric phosphate was generated [32].

Table 5. FTIR spectral characteristics of WMS before and after adsorption of $\mathrm{PO}_{4}{ }^{3-}$ ions.

\begin{tabular}{l|c|c|c|c|c}
\multirow{2}{*}{ No. } & \multicolumn{2}{|c|}{ Frequency spectrum $\left(\mathbf{c m}^{-\mathbf{1}}\right)$} & \multirow{2}{*}{$\begin{array}{c}\text { Detection of functional } \\
\text { group }\end{array}$} & Reference \\
\cline { 2 - 4 } & $\begin{array}{c}\text { Before } \\
\text { adsorption }\end{array}$ & $\begin{array}{c}\text { After } \\
\text { adsorption }\end{array}$ & Differences & & \\
\hline 1 & 3,547 & 3,564 & 17 & OH-stretching bands & {$[30]$} \\
\hline 2 & - & 2,359 & & O-H stretching band & {$[32]$} \\
\hline 3 & 1,451 & 1,458 & 7 & C-O stretching bands & {$[33]$} \\
\hline 4 & 857 & 860 & 3 & C-O stretching bands & {$[12],[29]$} \\
\hline 5 & 710 & 713 & 2 & C-O stretching bands & {$[12],[29]$}
\end{tabular}

\subsection{Adsorption of $\mathrm{PO}_{4}{ }^{3-}$ from a synthetic solution.}

The result of Figure 4a shows the variations of $E$ pursuant to $t$ for the adsorption of $\mathrm{PO}_{4}{ }^{3-}$ from a synthetic solution onto the WMS. The efficiency of $\mathrm{PO}_{4}{ }^{3-}$ removal can reach approximately $31.3,47.9$, and $75.1 \%$ for removing $\mathrm{PO}_{4}{ }^{3-}$ after $t$ of $120 \mathrm{~h}$ with the amounts of WMS used to run the experiments being 4, 12, and $20 \mathrm{~g}$, respectively. The $E$ rapidly increases during the first $2.5,3.5$, and $7.5 \mathrm{~h}$ and then continues to increase slowly until it reached an equilibrium state at $120 \mathrm{~h}$ (Figure 4a). The rapid adsorption of $\mathrm{PO}_{4}{ }^{3-}$ onto WMS from a synthetic solution during the initial stage of the experimental run may be due to the availability of many free active sites on the surface of the adsorbent [34].
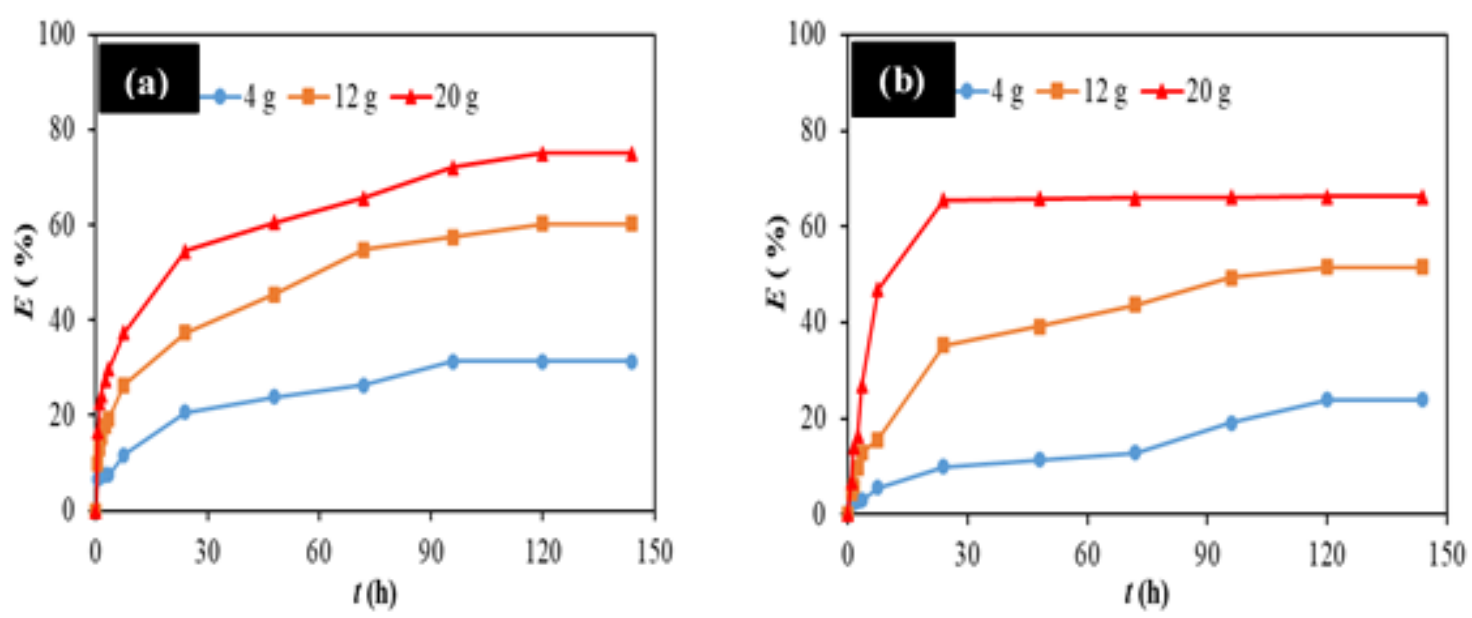

Figure 4. Variation of $E$ for the adsorption of $\mathrm{PO}_{4}{ }^{3-}$ onto WMS from (a) synthetic solution and (b) DWTPE.

The effects of different $m$ on both $E$ and $q$ for adsorption of $\mathrm{PO}_{4}{ }^{3-}$ onto WMS from synthetic solution was observed using 4, 8, 12, 16, and $20 \mathrm{~g}$ of the WMS as shown in Figure 5. The figure shows that $E$ for adsorption of $\mathrm{PO}_{4}{ }^{3-}$ gradually increases from 31.3 to $75.1 \%$; more adsorbent used could have more binding sites available to adsorb $\mathrm{PO}_{4}{ }^{3-}$ from a synthetic solution and thus the $E$ increases [27], but $q$ gradually decreases from 0.110 to $0.054 \mathrm{mg} \mathrm{g}^{-1}$ with the amounts of WMS increasing from 4 to $20 \mathrm{~g}$; the increase in the ratio of WMS to $\mathrm{PO}_{4}{ }^{3-}$ can lead to having more free active sites on the surface of WMS, resulted in comparatively less adsorption capacity at a higher amount of the WMS [35].

\subsection{Adsorption of $\mathrm{PO}_{4}{ }^{3-}$ from a DWTPE.}

The results of Figure $4 \mathrm{~b}$ shows the variation of $E$ pursuant to $t$ for the adsorption of $\mathrm{PO}_{4}{ }^{3-}$ onto the WMS from DWTPE. The removal efficiency of $\mathrm{PO}_{4}{ }^{3-}$ as shown in Figure $4 \mathrm{~b}$ 
can reach 23.9, 51.6, and 66.2\% using 4, 12, and $20 \mathrm{~g}$ of WMS, respectively. A slow increase in the efficiency of $\mathrm{PO}_{4}{ }^{3-}$ removal may be due to high concentrations of both $\mathrm{Cl}^{-}$and $\mathrm{SO}_{4}{ }^{2-}$ present in DWTPE can cause competition among the solutes of $\mathrm{PO}_{4}{ }^{3-}, \mathrm{SO}_{4}{ }^{2-}$ and $\mathrm{Cl}^{-}$for occupying the acceptor sites on the surface of WMS [36].

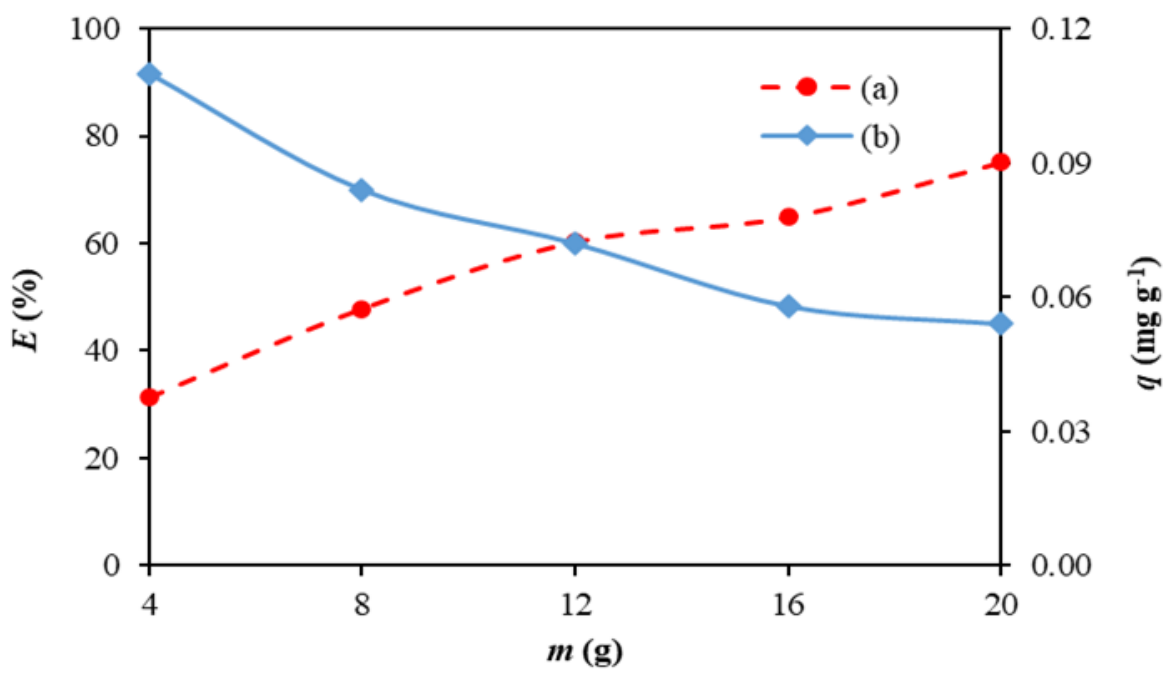

Figure 5. Relationship of: (a) $E$ for the adsorption of $\mathrm{PO}_{4}{ }^{3-}$ and (b) $q$ for the adsorption of $\mathrm{PO}_{4}{ }^{3-}$ onto WMS from synthetic solution.

A plot of either $E$ or $q$ against $m$ for adsorptions of $\mathrm{PO}_{4}{ }^{3-}$ onto WMS from DWTPE gives the curves as shown in Figure 6. The figure shows that $E$ for the adsorption of $\mathrm{PO}_{4}{ }^{3-}$ increase from 23.9 to $66.2 \%$, with an increase in the amount of WMS from 4 to $20 \mathrm{~g}$. The increase in $E$ could be due to the fact that the increased amount of the WMS may have increased the surface area and a number of active sites on the WMS, providing more possibility of adsorbing more $\mathrm{PO}_{4}{ }^{3-}$ ions [27], [36]. The value of $q$ decreases from 0.085 to $0.047 \mathrm{mg} \mathrm{g}^{-1}$ with an increasing amount of the WMS from 4 to $20 \mathrm{~g}$; this is due to the use of more WMS could be difficult to reach at a saturation condition [37]. At high WMS dosage, the available number of $\mathrm{PO}_{4}{ }^{3-}$ ion in the bulk solution was not enough to completely interact with all effective binding sites on the WMS surface, resulting in a surface equilibrium state and a reduction in the $q$ value per unit mass of adsorbent.

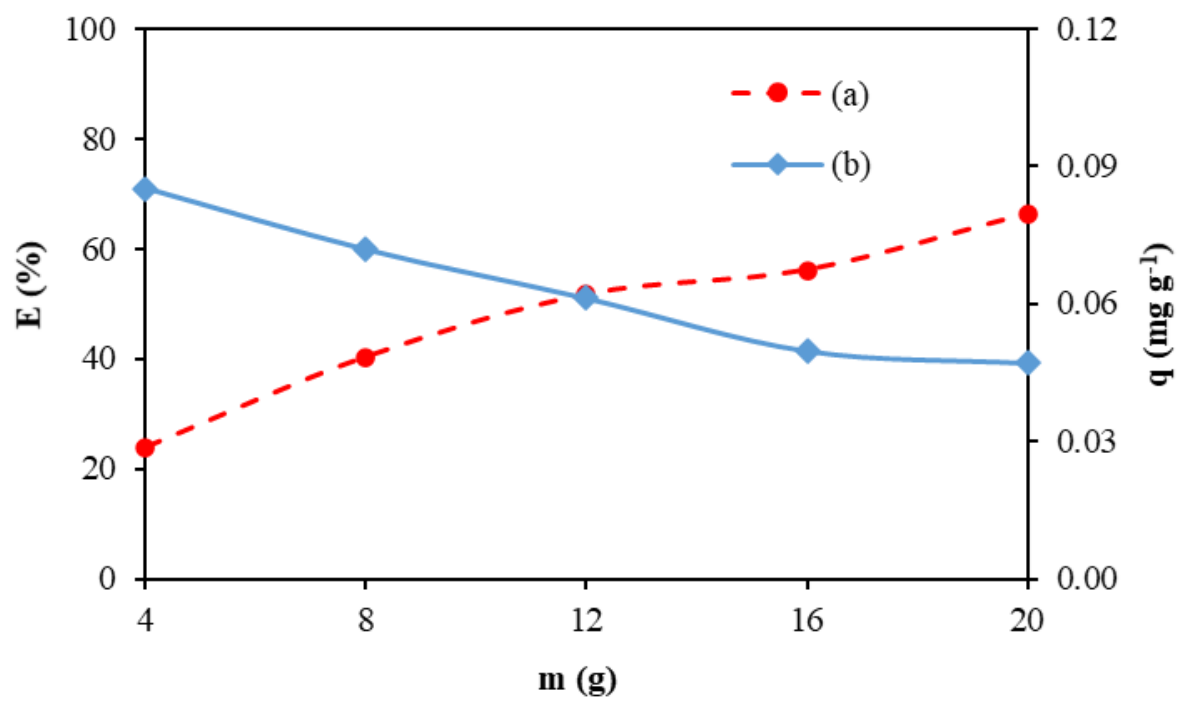

Figure 6. Relationship of: (a) $E$ for the adsorption of $\mathrm{PO}_{4}{ }^{3-}$ and (b) $q$ for the adsorption of $\mathrm{PO}_{4}{ }^{3-}$ onto WMS from DWTPE. 


\subsection{Adsorption kinetics of $\mathrm{PO}_{4}^{3-}$ onto the WMS.}

The linear regression analysis of the kinetic models for the adsorption of $\mathrm{PO}_{4}{ }^{3-}$ from a synthetic solution is shown in Figure 7. Table 6 shows the kinetic parameters $k_{1}, k_{2}$, and $q_{\mathrm{e}}$ for PFO and PSO models for the adsorption of $\mathrm{PO}_{4}{ }^{3-}$ onto WMS from synthetic solution and DWTPE. The value of $F_{\mathrm{e}}$ can be calculated according to the following equation [38]. The most appropriate model, either PFO or PSO should have the smallest $F_{\mathrm{e}}$ value and highest $R^{2}$ value.

$$
F_{e}=\sqrt{\left(\frac{1}{\bullet n-p}\right) \sum_{i}^{n}\left(q_{t(\exp )}-q_{t(\text { theo })}\right)^{2}}
$$

The linear kinetic curves obtained for the adsorption of $\mathrm{PO}_{4}{ }^{3-}$ from synthetic solution by WMS are depicted in Figure 7. As listed in Table 6, the correlation coefficient $\left(R^{2}>0.989\right)$ for PSO model was higher than that $\left(R^{2}>0.835\right)$ for PFO model; PSO model could be more suitable compared to PFO model due to the lower value of $F_{e}$, and the higher value of $R^{2}$ have been evaluated (Table 6). According to the results of this study, the adsorption between adsorbent-adsorbate can be categorized as chemisorption because of the adsorption process involving valency forces by sharing or exchanging electrons between the adsorbent and adsorbate (the replacement of $\mathrm{CO}_{3}{ }^{2-}$ by $\mathrm{PO}_{4}{ }^{3-}$ ) [39]. Similar results have been reported for the adsorption of $\mathrm{PO}_{4}{ }^{3-}$ onto raw shrimp shells [40]. Calcined waste eggshells [41] to show that the value of $k_{2}$ increases while the value of $q_{\mathrm{e}}$ decreases with an increasing amount of the adsorbent.
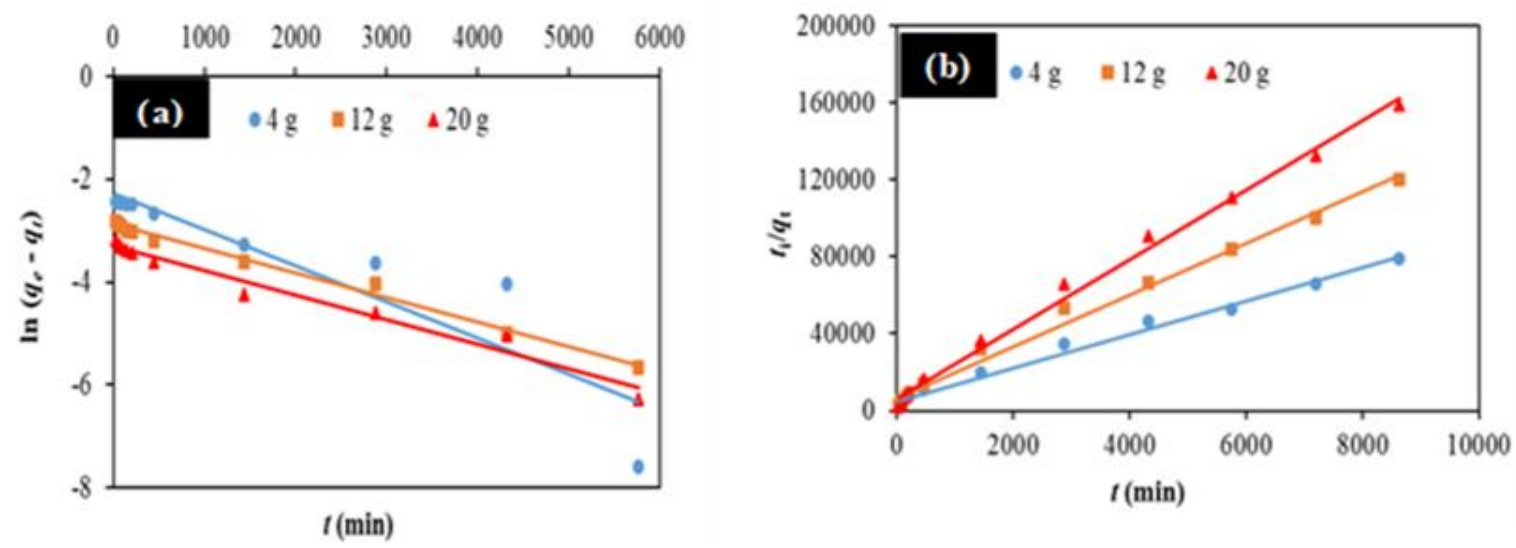

Figure 7. Linear regression analysis for the adsorption of $\mathrm{PO}_{4}{ }^{3-}$ onto WMS from a synthetic solution using (a) PFO model and (b) PSO model.
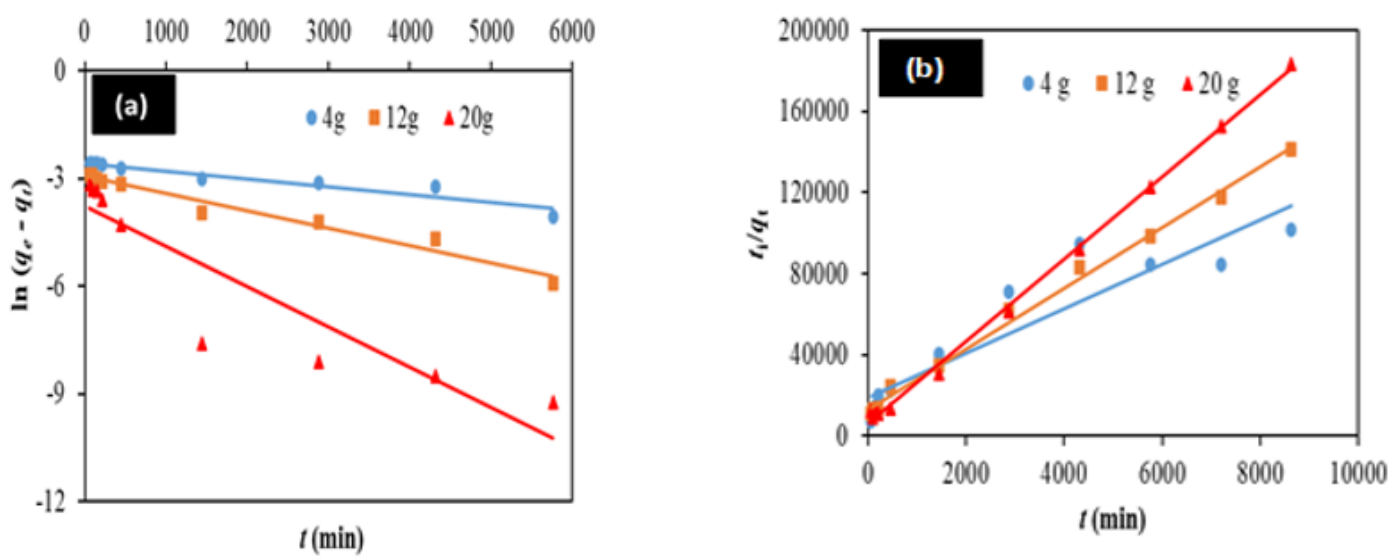

Figure 8. Linear regression analysis for the adsorption of $\mathrm{PO}_{4}{ }^{3-}$ onto WMS from DWTPE using (a) PFO model and (b) PSO model. 
The linear kinetic curves obtained for the adsorption of $\mathrm{PO}_{4}{ }^{3-}$ from DWTPE by WMS are shown in Figure 8. Correlation for the parameters in PSO model is good $\left(R^{2}>0.865\right)$ and is better than the PFO model $\left(R^{2}>0.842\right)$, while the $F_{\mathrm{e}}$ values for the PSO model are lower than for the PFO model for the adsorption of $\mathrm{PO}_{4}{ }^{3-}$ onto WMS from DWTPE (Table 6). In conclusion, the kinetic model for the adsorption of $\mathrm{PO}_{4}{ }^{3-}$ can be well described by PSO model. For PSO model, the values of $k_{2}$ increase with increasing the amount of WMS (Table 6) due to the fact that the adsorption of $\mathrm{PO}_{4}{ }^{3-}$ is faster with a higher amount of the WMS [41]. As can be seen in Table 6 , the values of $k_{2}$ are lower for the adsorption of $\mathrm{PO}_{4}{ }^{3-}$ from DWTPE than that from synthetic solution due to the competition between $\mathrm{PO}_{4}{ }^{3-}$ and other anions (i.e., $\mathrm{Cl}^{-}, \mathrm{NO}_{3}{ }^{-}$, and $\mathrm{SO}_{4}{ }^{3-}$ ) that exist in DWTPE (see Table 3), which may impede the mobilization of $\mathrm{PO}_{4}{ }^{3-}$ ions to reach the active sites at the surface of WMS [41].

\subsection{Adsorption isotherms of $\mathrm{PO}_{4}{ }^{3-}$ onto the WMS.}

The experimental data for the adsorption of $\mathrm{PO}_{4}{ }^{3-}$ onto WMS from synthetic solution and DWTPE were analyzed using the linearized forms of the Freundlich and Langmuir models. All the values of the parameters calculated using these two isotherm models are listed in Table 7. This study found that the experimental data were best described by the Freundlich isotherm model (Figure 9a and Figure 10a) compared with the Langmuir isotherm model (Figure 9b and Figure 10b) due to the values of $R^{2}$ close to 1 for the adsorption of $\mathrm{PO}_{4}{ }^{3-}$ onto WMS from either synthetic solution or DWTPE (Table 7). The adsorption of $\mathrm{PO}_{4}{ }^{3-}$ occurred on the heterogeneous site of WMS progression with multilayer adsorption where the adsorbed $\mathrm{PO}_{4}{ }^{3-}$ on the WMS surface can attract more $\mathrm{PO}_{4}{ }^{3-}$ from the bulk water. The surfaces of the WMS are heterogeneous, and sorption of $\mathrm{PO}_{4}{ }^{3-}$ onto WMS occurs in the form of multilayers [42], [43]. The adsorption of $\mathrm{PO}_{4}{ }^{3-}$ from synthetic solution would be more favorable than that from DWTPE because of the $n$ value of 1.33 for the adsorption of $\mathrm{PO}_{4}{ }^{3-}$ from the synthetic solution, which is higher than the 1.28 recorded for the adsorption of $\mathrm{PO}_{4}{ }^{3-}$ from DWTPE as was verified [44].

Table 6. Kinetic parameters were obtained from the PFO and PSO models for the adsorption of $\mathrm{PO}_{4}{ }^{3-}$ onto WMS from synthetic solution and DWTPE.

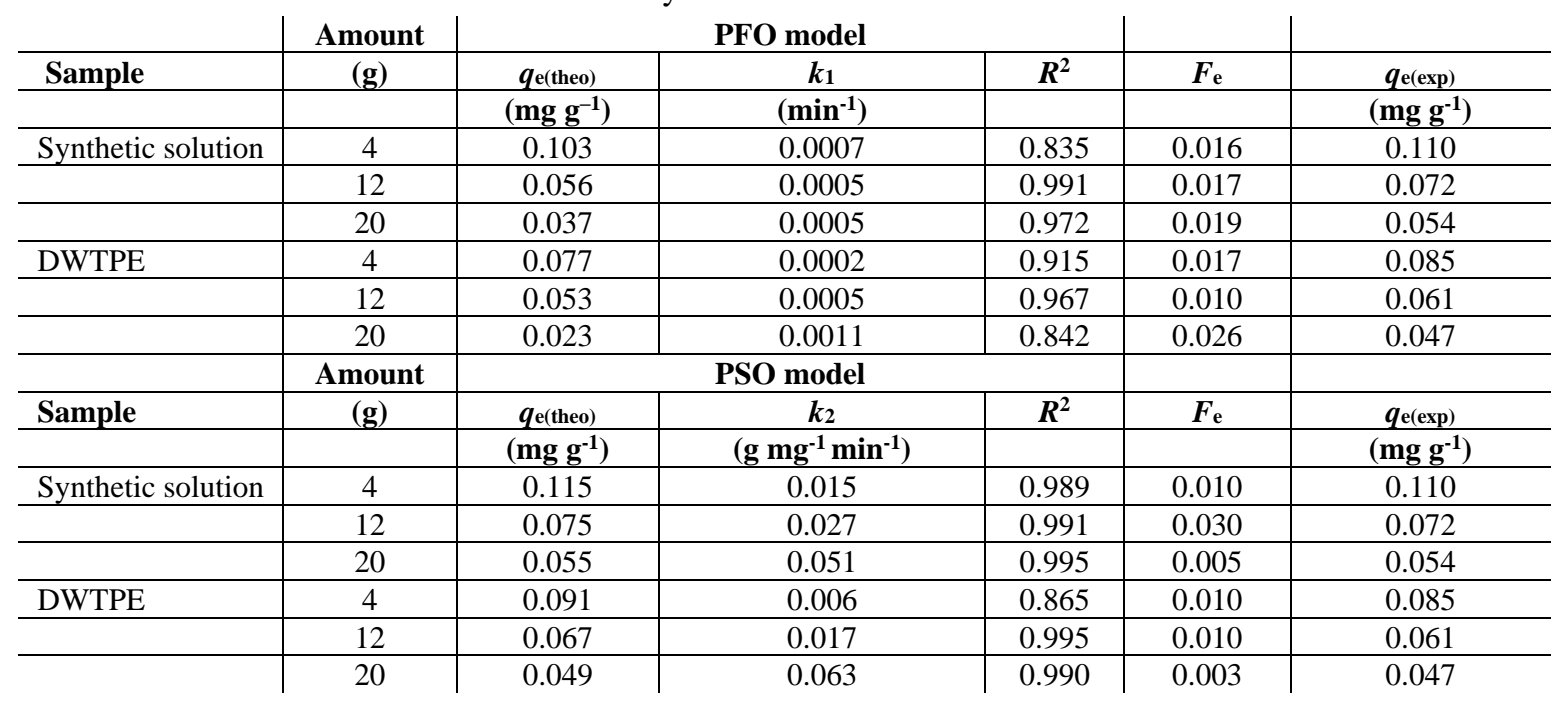



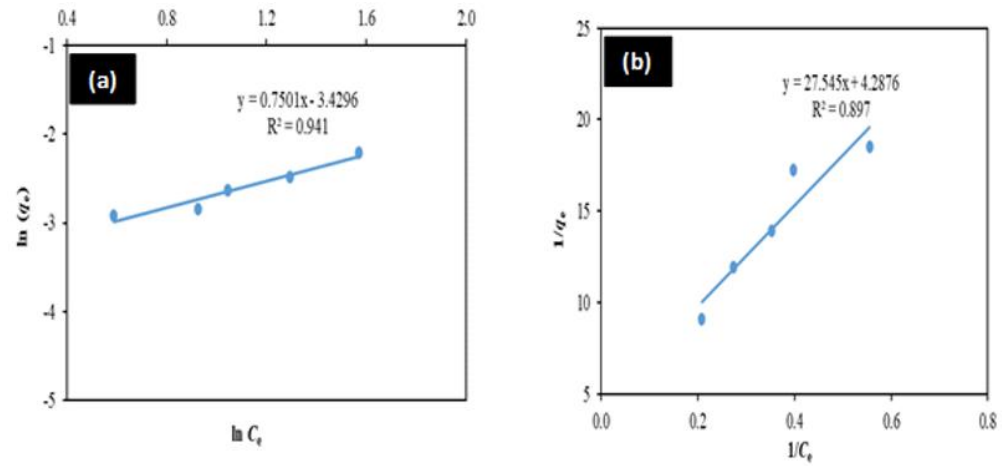

Figure 9. Linear line of plotting (a) $\ln \left(q_{\mathrm{e}}\right)$ versus $\ln \left(C_{\mathrm{e}}\right)$ and (b) $1 / q_{\mathrm{e}}$ versus $1 / C_{\mathrm{e}}$ for the adsorption of $\mathrm{PO}_{4}{ }^{3-}$ onto WMS from synthetic solution.
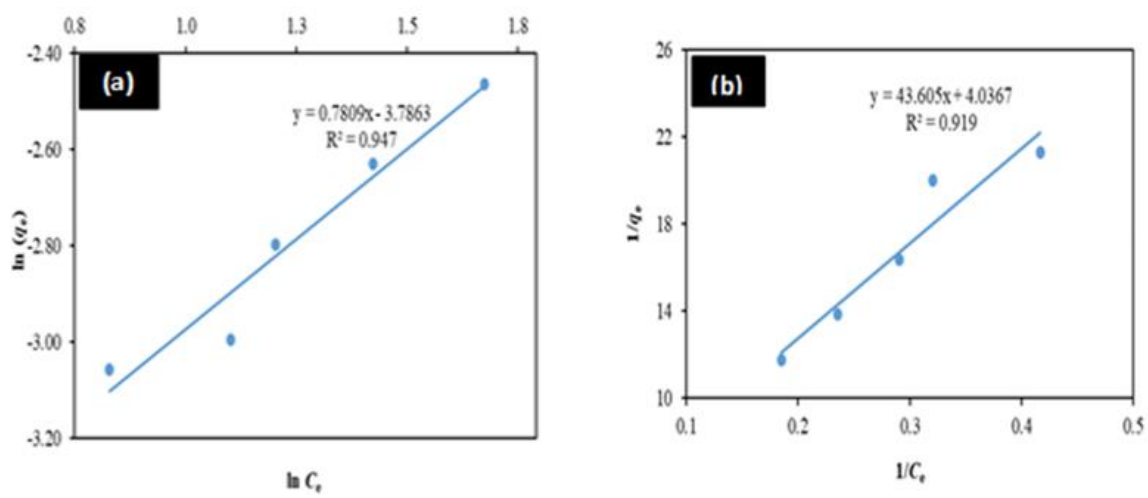

Figure 10. Linear line of plotting (a) $\ln \left(q_{\mathrm{e}}\right)$ versus $\ln \left(C_{\mathrm{e}}\right)$ and (b) $1 / q_{\mathrm{e}}$ versus $1 / C_{\mathrm{e}}$ for the adsorption of $\mathrm{PO}_{4}{ }^{3-}$ onto WMS from DWTPE.

As enumerated in Table 7, the constant $K_{\mathrm{F}}$ (i.e., $0.032 \mathrm{mg} \mathrm{g}^{-1}$ ) for the adsorption of $\mathrm{PO}_{4}{ }^{3-}$ from synthetic solution is higher than that from DWTPE onto WMS (i.e., $0.023 \mathrm{mg} \mathrm{g}^{-1}$ ). This could be due to an easy uptake of $\mathrm{PO}_{4}{ }^{3-}$ ions from the synthetic solution since there are no competing anions present in the synthetic solution that may affect the migration of $\mathrm{PO}_{4}{ }^{3-}$ from solution to occupy the active sites at the surface of the WMS [45]. The $n$ values of 1.33 and 1.28 were verified for the adsorption of $\mathrm{PO}_{4}{ }^{3-}$ onto WMS from synthetic solution and DWTPE, respectively. The value of $n$ higher than 1 could be favorable for the sorption of $\mathrm{PO}_{4}{ }^{3-}$ onto WMS, indicating that active sites with the highest binding energies are utilized first for less heterogeneous surfaces and then followed by weaker sites for more heterogeneous surfaces [46].

Table 7. The parameters $n, K_{\mathrm{F}}, q_{\mathrm{max}}$, and $K_{\mathrm{L}}$ for the adsorption of $\mathrm{PO}_{4}{ }^{3-}$ onto WMS from synthetic solution and DWTPE.

\begin{tabular}{l|c|c|c|c|c|c} 
& \multicolumn{3}{|c|}{ Freundlich model } & \multicolumn{3}{c}{ Langmuir model } \\
\hline Sample & $\boldsymbol{n}$ & $\boldsymbol{K}_{\mathbf{F}}$ & $\boldsymbol{R}^{\mathbf{2}}$ & $\boldsymbol{q}_{\mathbf{m a x}}$ & $\boldsymbol{K}_{\mathbf{L}}$ & $\boldsymbol{R}^{\mathbf{2}}$ \\
\hline Synthetic solution & & $\mathbf{( \mathbf { m g ~ g } ^ { - 1 } )}$ & & $\left.\mathbf{m g ~ g}^{-1}\right)$ & $\left(\mathbf{L} \mathbf{~ m g}^{-1}\right)$ & \\
\hline DWTPE & 1.33 & 0.032 & 0.941 & 0.233 & 0.156 & 0.897 \\
\hline
\end{tabular}

\section{Conclusions}

In this work, the verification of kinetic and isotherm models has been performed to describe the mechanism of the adsorption of $\mathrm{PO}_{4}{ }^{3-}$ from synthetic solution and DWTPE onto WMS. The adsorption kinetic data were well fitted to the PSO model, suggesting that the adsorption phenomena for removing $\mathrm{PO}_{4}{ }^{3-}$ from synthetic solution and DWTPE by adsorbing onto WMS could be leading to chemisorption. The adsorption isotherm data can be described 
well with the Freundlich model, suggesting that adsorption of $\mathrm{PO}_{4}{ }^{3-}$ onto WMS from both synthetic solution and DWTPE is more likely a multilayer adsorption process. The present study demonstrated that WMS could serve as a promising adsorbent for $\mathrm{PO}_{4}{ }^{3-}$ removal from waters and make substantial contributions to improving environmental quality.

\section{Funding}

We thank the Ministry of Higher Education for financial support (Fundamental Research Grant Scheme: Vote Number: 4F956).

\section{Acknowledgments}

We thank the Centre for Environmental Sustainability and Water Security (IPASA) for laboratory facilities and Indah Water Konsortium (IWK) Sdn. Bhd. for research collaboration.

\section{Conflicts of Interest}

The authors declare no conflict of interest.

\section{References}

1. Wu, K.; Li, Y.; Liu, T.; Huang, Q.; Yang, S.; Wang, W.; Jin, P. The simultaneous adsorption of nitrate and phosphate by an organic-modified aluminum-manganese bimetal oxide: Adsorption properties and mechanisms. Applied Surface Science 2019, 478, 539-551, https://doi.org/10.1016/j.apsusc.2019.01.194.

2. Le Moal, M.; Gascuel-Odoux, C.; Ménesguen, A.; Souchon, Y.; Étrillard, C.; Levain, A.; Moatar, F.; Pannard, A.; Souchu, P.; Lefebvre, A.; Pinay, G. Eutrophication: A new wine in an old bottle? Science of the Total Environment 2019, 651, 1-11, https://doi.org/10.1016/j.scitotenv.2018.09.139.

3. Li, R.; Wang, J.J.; Zhou, B.; Awasthi, M.K.; Ali, A.; Zhang, Z.; Mahar, A. Enhancing phosphate adsorption by $\mathrm{Mg} / \mathrm{Al}$ layered double hydroxide functionalized biochar with different $\mathrm{Mg} / \mathrm{Al}$ ratios. Science of the Total Environment 2016, 559, 121-129, https://doi.org/10.1016/j.scitotenv.2016.03.151.

4. Kumar, P.S.; Korving, L.; van Loosdrecht, M.C.M.; Witkamp, G.J. Adsorption as a technology to achieve ultra-low concentrations of phosphate: Research gaps and economic analysis. Water Research X 2019, 4, 100029, https://doi.org/10.1016/j.wroa.2019.100029.

5. Abdul Salim, N.A.; Abdullah, N.H.; Khairuddin, M.R.; Rudie Arman, M.A.Z.; Khamidun, M.H.; Fulazzaky, M.A.; Puteh, M.H. Adsorption of phosphate from aqueous solutions using waste mussel shell. MATEC Web of Conferences 2018, 250, https://doi.org/10.1051/matecconf/201825006013.

6. Karri, R.R.; Sahu, J.N.; Chimmiri, V.Critical review of abatement of ammonia from wastewater. Journal Molecular Liquid 2018, 261, 21-31, doi: 10.1016/j.molliq.2018.03.120.

7. Lalley, J.; Han, C.; Li, X.; Dionysiou, D.D.; Nadagouda, M.N. Phosphate adsorption using modified iron oxide-based sorbents in lake water: Kinetics, equilibrium, and column tests. Chemical Engineering Journal 2016, 284, 1386-1396, https://doi.org/10.1016/j.cej.2015.08.114.

8. Gupta, V.K.; Sadegh, H.; Yari, M.; Shahryari Ghoshekandi, R.; Maazinejad, B.; Chahardori, M. Removal of ammonium ions from wastewater A short review in development of efficient methods. Global Journal of Environmental Science and Management 2015, 1, 149-158, https://doi.org/10.7508/gjesm.2015.02.007.

9. Ahmed, S.; Ashiq, M.N.; Li, D.; Tang, P.; Leroux, F.; Feng, Y. Recent progress on adsorption materials for phosphate removal. Recent Patents on Nanotechnology 2019, 13, 3-16, https://doi.org/10.2174/1872210513666190306155245.

10. Kong, L.; Tian, Y.; Pang, Z.; Huang, X.; Li, M.; Li, N.; Zhang, J.; Zuo, W.; Li, J. Needle-like Mg-La bimetal oxide nanocomposites derived from periclase and lanthanum for cost-effective phosphate and fluoride removal: Characterization, performance and mechanism. Chemical Engineering Journal 2020, 382, https://doi.org/10.1016/j.cej.2019.122963.

11. Pap, S.; Kirk, C.; Bremner, B.; Turk Sekulic, M.; Gibb, S.W.; Maletic, S.; Taggart, M.A. Synthesis optimisation and characterisation of chitosan-calcite adsorbent from fishery-food waste for phosphorus removal. Environmental Science and Pollution Research 2020, 27, 9790-9802, https://doi.org/10.1007/s11356-019-07570-0.

12. Kim, Y.; Kim, D.; Kang, S.W.; Ham, Y.H.; Choi, J.H.; Hong, Y.P.; Ryoo, K.S. Use of powdered cockle shell as a bio-sorbent material for phosphate removal from water. Bulletin of the Korean Chemical Society 2018, 39, 1362-1367, https://doi.org/10.1002/bkcs.11606. 
13. Nam, G.; Choi, Y.-H.H.; Lee, N.; Ahn, J.W. Effect by alkaline flocculation of algae and phosphorous from water using a calcined waste oyster shell. Water (Switzerland) 2017, 9, https://doi.org/10.3390/w9090661.

14. Sainudin, M.S.; Othman, N.H.; Shahidan, S. Performance of concrete containing mussel shell (Perna viridis) ash under effect of sodium chloride curing. IOP Conference Series: Materials Science and Engineering 2019, 601, https://doi.org/10.1088/1757-899X/601/1/012033.

15. El Haddad, M. Removal of Basic Fuchsin dye from water using mussel shell biomass waste as an adsorbent: Equilibrium, kinetics, and thermodynamics. Journal of Taibah University for Science 2016, 10, 664-674, https://doi.org/10.1016/j.jtusci.2015.08.007.

16. Wang, Q.; Peng, L.; Gong, Y.; Jia, F.; Song, S.; Li, Y. Mussel-inspired $\mathrm{Fe}_{3} \mathrm{O}_{4} @$ Polydopamine (PDA)-MoS 2 core-shell nanosphere as a promising adsorbent for removal of $\mathrm{Pb}^{2+}$ from water. Journal of Molecular Liquids 2019, 282, 598-605, https://doi.org/10.1016/j.molliq.2019.03.052.

17. Liu, Y.; Shen, L. From Langmuir kinetics to first- and second-order rate equations for adsorption. Langmuir 2008, 24, 11625-11630, https://doi.org/10.1021/la801839b.

18. Lagergren S. About the theory of so-called adsorption of soluble substances. K. Sven. Vetenskapsakad Handlinge 1898, 24, 1-39.

19. Blanchard, G.; Maunaye, M.; Martin, G. Removal of heavy metals from waters by means of natural zeolites. Water Research 1984, 18, 1501-1507, https://doi.org/10.1016/0043-1354(84)90124-6.

20. Rashidi Nodeh, H.; Sereshti, H.; Zamiri Afsharian, E.; Nouri, N. Enhanced removal of phosphate and nitrate ions from aqueous media using nanosized lanthanum hydrous doped on magnetic graphene nanocomposite. Journal of Environmental Management https://doi.org/10.1016/j.jenvman.2017.04.004.

21. Singh, N.B.; Nagpal, G.; Agrawal, S.; Rachna. Water purification by using adsorbents: A Review. Environmental Technology and Innovation 2018, 11, 187-240, https://doi.org/10.1016/j.eti.2018.05.006.

22. Freundlich, H. Over the adsorption in solution. The Journal of Physical Chemistry 1906, 57, 384-470.

23. Langmuir, I. The adsorption of gases on plane surfaces of glass, mica and platinum. Journal of the American Chemical Society 1918, 40, 1361-1403, https://doi.org/10.1021/ja02242a004.

24. American Public Health Association (APHA), Standard Methods for the Examination of Water and Wastewater. 21st ed., Springer, Washington DC, 2005.

25. Saharudin, S.H.; Shariffuddin, J.H.; Ismail, A.; Mah, J.H. Recovering value from waste: Biomaterials production from marine shell waste. Bulletin of Materials Science 2018, 41, 1-8, https://doi.org/10.1007/s12034-018-1680-5.

26. Nurdin, S.; Rosnan, N.A.; Ghazali, N.S.; Gimbun, J.; Nour, A.H.; Haron, S.F. Economical Biodiesel Fuel Synthesis from Castor Oil Using Mussel Shell-Base Catalyst (MS-BC). Energy Procedia 2015. 79, 576-583, https://doi.org/10.1016/j.egypro.2015.11.536.

27. Torit, J.; Phihusut, D. Phosphorus removal from wastewater using eggshell ash. Environmental Science and Pollution Research 2019, 26, 34101-34109, https://doi.org/10.1007/s11356-018-3305-3.

28. Fu, H.; Yang, Y.; Zhu, R.; Liu, J.; Usman, M.; Chen, Q.; He, H. Superior adsorption of phosphate by ferrihydrite-coated and lanthanum-decorated magnetite. Journal of Colloid and Interface Science 2018, 530, 704-713, https://doi.org/10.1016/j.jcis.2018.07.025.

29. Mitrogiannis, D.; Psychoyou, M.; Baziotis, I.; Inglezakis, V.J.; Koukouzas, N.; Tsoukalas, N.; Markou, G. Removal of phosphate from aqueous solutions by adsorption onto $\mathrm{Ca}(\mathrm{OH})_{2}$ treated natural clinoptilolite. Chemical Engineering Journal 2017, 320, 510-522, https://doi.org/10.1016/j.cej.2017.03.063.

30. Hajar, S.; Haslinda, J.; Ida, N.; Ahamad, A. Effect of aging time in the synthesis of biogenic hydroxyapatite derived from cockle shell. Materials Today: Proceedings 2019, 19, 1208-1215, https://doi.org/10.1016/j.matpr.2019.11.124.

31. Wu, S.-C. C.; Hsu, H.-C. C.; Hsu, S.-K. K.; Tseng, C.-P. P.; Ho, W.-F. F. Preparation and characterization of hydroxyapatite synthesized from oyster shell powders. Advanced Powder Technology 2017, 28, 11541158, https://doi.org/10.1016/j.apt.2017.02.001.

32. Liu, Q.; Guo, L.; Zhou, Y.; Dai, Y.; Feng, L.; Zhou, J.; Qian, G. Phosphate adsorption on biogenetic calcium carbonate minerals: Effect of a crystalline phase. Desalination and Water Treatment 2012, 47, 78-85, https://doi.org/10.1080/19443994.2012.696798.

33. Wu, S.-C.C.; Hsu, H.-C.C.; Hsu, S.-K.K.; Tseng, C.-P.P.; Ho, W.-F.F. Preparation and characterization of hydroxyapatite synthesized from oyster shell powders. Advanced Powder Technology 2017, 28, 1154-1158, https://doi.org/10.1016/j.apt.2017.02.001.

34. Salim, N.A.A.; Puteh, M.H.; Yusoff, A.R.M.; Abdullah, N.H., Fulazzaky, M.A.; Rudie Arman, M.A.Z.; Zainuddin, N.A. Adsorption isotherms and kinetics of phosphate on waste mussel shell. Malaysian Journal of Fundamental and Apllied Sciences 2020, 16, 393-399.

35. Panda, H.; Tiadi, N.; Mohanty, M.; Mohanty, C.R. Studies on adsorption behavior of an industrial waste for removal of chromium from aqueous solution. South African Journal of Chemical Engineering 2017, 23, 132-138, https://doi.org/10.1016/j.sajce.2017.05.002.

36. Afridi, M.N.; Lee, W.-H.H.; Kim, J.-O.O. Effect of phosphate concentration, anions, heavy metals, and organic matter on phosphate adsorption from wastewater using anodized iron oxide nanoflakes. Environmental Research 2019, 171, 428-436, https://doi.org/10.1016/j.envres.2019.01.055. 
37. Zhai, L.; Bai, Z.; Zhu, Y.; Wang, B.; Luo, W. Fabrication of chitosan microspheres for efficient adsorption of methyl orange. Chinese Journal of Chemical Engineering 2018, 26, 657-666, https://doi.org/10.1016/j.cjche.2017.08.015.

38. Ribas, M.C.; Adebayo, M.A.; Prola, L D T.; Lima, E.C.; Cataluña, R.; Feris, L.A.; Calvete, T. Comparison of a homemade cocoa shell activated carbon with commercial activated carbon for the removal of reactive violet 5 dye from aqueous solutions. Chemical Engineering Journal 2014, 248, 315-326, https://doi.org/10.1016/j.cej.2014.03.054.

39. Theophile, T.; Berzina-Cimdina, L.; Borodajenko, N. Research of Calcium Phosphates Using Fourier Transform Infrared Spectroscopy. InTech Published, Croatia, 2012, 576-583, https://doi.org/10.5772/36942.

40. Abidar, F.; Morghi, M.; Abali, M.; Sinan, F.; Chiban, M.; Eddaoudi, H.; Zebret, M. Orthophosphate ion adsorption onto raw shrimp shells. Journal of Water Science 2017, 29, 197-211, https://doi.org/10.7202/1038924ar.

41. Panagiotou, E.; Kafa, N.; Koutsokeras, L.; Kouis, P.; Nikolaou, P., Constantinides, G.; Vyrides, I. Turning calcined waste egg shells and wastewater to Brushite: Phosphorus adsorption from aqua media and anaerobic sludge leach water. Journal of Cleaner Production 2018, 178, 419-428, https://doi.org/10.1016/j.jclepro.2018.01.014.

42. Almasri, D.A.; Saleh, N.B.; Atieh, M.A.; McKay, G.; Ahzi, S. Adsorption of phosphate on iron oxide doped halloysite nanotubes. Scientific Reports 2019, 9, https://doi.org/10.1038/S41598-019-39035-2.

43. Arshadi, M.; Mousavinia, F.; Amiri, M.J.; Faraji, A.R. Adsorption of methyl orange and salicylic acid on a nano-transition metal composite: Kinetics, thermodynamic and electrochemical studies. Journal of Colloid and Interface Science 2016, 483, 118-131, https://doi.org/10.1016/j.jcis.2016.08.032.

44. Ajmal, Z.; Muhmood, A.; Usman, M.; Kizito, S.; Lu, J.; Dong, R.; Wu, S. Phosphate removal from aqueous solution using iron oxides: Adsorption, desorption and regeneration characteristics. Journal of Colloid and Interface Science 2018, 528, 145-155, https://doi.org/10.1016/j.jcis.2018.05.084.

45. Pohndorf, R.S.; Cadaval, T.R.S.; Pinto, L.A.A. Kinetics and thermodynamics adsorption of carotenoids and chlorophylls in rice bran oil bleaching. Journal of Food Engineering 2016, 185, 9-16, https://doi.org/10.1016/j.jfoodeng.2016.03.028.

46. Li, L.; Qiao, Q.; Zhou, G.; Qi, Y.; Lim, Z.H.; Chau, F.S.; Zhou, G. Design of an on-chip Fourier transform spectrometer based on waveguide mach-zehnder interferometer and fluidics. Optics Communications 2020, 460, https://doi.org/10.1016/j.optcom.2019.125103. 